\title{
RE-READING ROALD DAHL FROM AN ECOLOGICAL PERSPECTIVE
}

\author{
María Augusta Albuja Aguilar \\ Universidad Complutense de Madrid
}

\begin{abstract}
Concerning the study of children's literature, contemporary ecocritical research proposes to analyze how ecological narratives diverge from the logic of alienation, hierarchy and domination and move towards inspiring community and interdependence. Roald Dahl's (1916-1990) respect and deep knowledge of nature and animals are rendered in most of his children's novels, depicting underdogs working together to defeat oppression and abuse of power. Given that these stories have long been part of popular culture, as well as the school curricula, this paper studies them from an ecological perspective arguing that, through similar re-readings, these narratives could inspire environmental consciousness and agency in young readers.
\end{abstract}

KeYwords: Roald Dahl, ecocriticism, ecological narratives, children's environmental literature, nature, anthropomorphism.

\author{
RELEYENDO A ROALD DAHL \\ DESDE UNA PERSPECTIVA ECOLÓGICA
}

\section{RESUMEN}

En cuanto a los estudios de la literatura infantil, la investigación dentro de la ecocrítica contemporánea sugiere analizar la forma en cómo las narrativas ecológicas logran alejarse de la lógica de la alienación, jerarquía y dominación y en su lugar promueven la comunidad y la interdependencia. Gran parte de las novelas infantiles de Roald Dahl (1916-1990) expresan un profundo conocimiento y respeto a la naturaleza y los animales, y muestran seres oprimidos trabajando juntos para enfrentarse y derrotar el abuso de poder. Tomando en cuenta que durante mucho tiempo estas historias han formado parte de la cultura popular, así como de los temarios escolares, este artículo las estudia desde una perspectiva ecológica y argumenta que, a través de relecturas similares, estas narrativas podrían inspirar una conciencia y conducta ambiental en los jóvenes lectores.

Palabras Clave: Roald Dahl, ecocrítica, narrativas ecológicas, literatura infantil ambiental, naturaleza, antropomorfismo.

DOI: https://doi.org/10.25145/j.recaesin.2022.84.12

Revista Canaria de Estudios Ingleses, 84; April 2022, pp. 169-181; ISSN: e-2530-8335 
Roald Dahl (1916-1990) wrote and published during World War II, the postwar period and the Cold War, a time that witnessed technological developments, but also a nuclear race and mass destruction. The former RAF pilot gained popularity thanks to his gothic horror short stories and fantastic children's novels -which even became part of the school curricula, while also facing challenges along the way. As a young man, Dahl lived in African rural areas and later became a countryman in Buckinghamshire, and several of his stories are inspired by his love and knowledge of the natural world, as well as his Nordic folk heritage. Most of the criticism concerning his works -which has increased during the last decades due to a growing interest in popular and children's literature- focuses on literary, philosophical, social, and pedagogical analysis, whereas little has been said about Dahl's depictions of nature, animals, and environmental takes throughout these narratives.

In this regard, The Gremlins (1943) and The BFG (1982) advocate against the destruction of the planet and other species, while Billy and The Minpins (1991) comments on habitat conservation and knowledge. According to Hollindale, Beatrix Potter "combined witty anthropomorphism with meticulous observation of wild creatures" $(2011,163)$, a remark that suits Dahl's works against mistreating animals like James and the Giant Peach (1961), Fantastic Mr. Fox (1970), The Twits (1980) and the Dirty Beasts' poem "The Pig" (1983), as well as his novels devoted to discouraging hunting like The Magic Finger (1966) and Danny, the Champion of the World (1975).

According to Hollindale, the term "nature" has had different uses historically and literary regarding the "treatment of children and the emergence of children's books" $(2011,161)$. There has been a concern with both human nature -birth, education, socialization, and independence- and the natural world, and also with the relationship among them which, due to overpopulation, technology and climate change, has been acquiring new meanings that influence the study of children's literature (Hollindale 2011, 163-164). As a result, we first introduce a general approach to the relationship between children's literature and nature, followed by an analysis of selected works by Roald Dahl depicting the natural world and nonhuman beings; finally, we argue that rereading and studying these narratives from an ecological perspective could inspire environmental consciousness and agency in young readers.

\section{NATURE IN CHILDREN'S LITERATURE}

Before the second half of the twenty century and especially with the publication of Dr. Seuss' (1904-1991) The Lorax (1971) that marked the seventies as a peak for ecologically aware books for children, not only anthropocentric, but pastoral representations often created an idealistic portrait of nature making it a mere escape from the urban industrialized life (Sigler 1994, 148). Hollindale points out how young classics often employed magic and mystical tropes and depicted a special connection between children and the environment through "independent, secret and unsupervised play in natural settings" (2011, 163). Fantastic Victorian works took the same road creating worlds like Wonderland and Neverland as a metaphor 
to existential growing pains and it is not until the emergence of a more radicalized pastoral that sought to retrieve children's literature didactic function-encouraging animal care and empathy to the underprivileged-that non-human beings were granted a voice, anticipating a modern pastoral tradition that went beyond civilized settings like gardens and parks, to represent wildlife (Sigler 1994, 149-152).

More recent contributions depict urban spaces as endangered and refer to real natural areas in the world, not only encouraging to appreciate their beauty or informing about their ecological dangers, but also urging on socio-environmental debates -that include topics such as multiculturalism, feminism, nuclear power, and animal rights- and empowering children for eco-activism (Sigler 1994, 149-152). Gaard argues that narratives for young readers that emphasize how to defeat alienation, hierarchy, and domination, often encourage community and interdependence, as well as anarchy and agency and in these stories, children consider the perspective of the non-human world and are open to change thanks to interaction and empathy $(2008,12-15)$. Values that can be found in Dahl's works where underdogs -often poor and orphaned children, vulnerable magical creatures and small animals- work together and mobilize to defeat authority and abuse of power.

In this context, Ecocriticism, as a theoretical framework, has expanded its scope during the last decades to include class disparities and feminist approaches which have connected environmental justice issues to oppressive structures (Gaard $2008,12)$. According to Gaard, to study children's fiction from this perspective, we should first observe how are humans and the natural world's identities constructed in the narrative and how do they face alienation; second, identify how the narrative addresses the ecojustice problem and if the strategy to solve it is appropriate in terms of rejecting hierarchy and promoting participation and community, and in this sense, examine if the child is left on its own to solve an environmental problem caused by adults; and third, we must analyse the kind of agency that the text recognizes in nature questioning whether it is portrayed as self-reliant or if it is saved by the child hero $(2008,15-18)$. These matters will be addressed next throughout the analysis of Dahl's works with an emphasis on nature, to see how they extrapolate from the logic of domination towards encouraging environmental consciousness and agency in children.

\section{"THE HUMAN BEANS IS MAKING RULES TO SUIT THEMSELVES"}

Dahl's first story marketed for children The Gremlins -with illustrations by Walt Disney Productions- was published during World War II when Dahl served as a RAF pilot, and draws from aircrew folklore that attributed mechanical failures to mythical creatures. The story explains why the gremlins' goal is to destroy planes, stating that, long time ago, England was covered with forests and swamps where goblins, trolls, hobgoblins, pixies, and the gremlins-in the greenest of the woodslived peacefully until the humans came $(1943,17)$. The story continues: 
... for one morning their world was suddenly filled with a tremendous rumbling that shook their little houses and even the big trees. [...] From the trucks jumped hundreds of humans [...] who started cutting down the trees [...]. There was nothing for the little men to do but to move very quickly onto a hill nearby, where they just sat watching the humans who were destroying their homes. [...] And as the days went by, the little people saw a huge factory rise on the spot where the wood had been. (Dahl 1943, 17-18)

The gremlins realize that the factory is destined for aeroplane assembly and decide to make mischief with "those big tin birds" from then on (Dahl 1943, 18). Unfortunately, the story ends on a different note when the creatures change their mission to help one pilot - harmed after a war accident- to fly again and be able to go back to fighting against the German squadron. ${ }^{1}$

A year later, the New Yorker published Dahl's The Sound Machine (1949), a horror story about a device that allows the human ear to hear the sharpest sounds, where the inventor becomes deeply affected by the sounds that flowers and trees make when they are cut. Even if the story is directed to an older audience, this poignant idea is rendered in one of Dahl's most popular children's books, The BFG, the story of a dreams' collector giant, who befriends an orphan girl named Sophie and work together -with a little help from the Queen of England- to defeat the horrible giants that eat children at night when they are asleep.

In one of their conversations, the Big Friendly Giant explains to Sophie that he can hear the sharpest sounds, like ladybirds and ants passing by, but also plants and trees -for instance, referring to picking a flower and twisting its stem till it breaks, the BFG says: "it is screaming just like you would be screaming if someone was twisting your arm right off" (Dahl 2016b, 37). This comparison of nonhuman to human pain is later expanded throughout the following dialogue:

'... I is hearing a terrible sound coming from inside the heart of the tree.'

'What sort of sound?' Sophie asked.

'A soft moaning sound,' the BFG said. 'It is like the sound an old man is making when he is dying slowly.'

He paused. The cave was very silent.

'Trees is living and growing just like you and me,' he said. 'They is alive. So is plants.' (Dahl 2016b, 38)

Even if the main plot of this novel is not about ecojustice, the BFG seems to be environmentally conscious. He does not only empathize with other creatures' feelings, but also chooses not to eat humans out of respect because they do not harm giants, and he remains a vegetarian that only eats snozzcumbers. In this sense, the

1 The plot is expanded in Dahl's post-apocalyptic novel Some Time Never: A Fable for Supermen (1948) -which has gone out of print but was "notable for being perhaps the first fictional account of nuclear war to be published" after the Hiroshima and Nagasaki bombings ("Some Time Never," The Official Roald Dahl Website). 
BFG argues that the "little piggy-wig" says "I have never done any harm to the human bean so why should he be eating me?" (Dahl 2016b, 71), emphasizing how humans make rules only to suit themselves and are the only species that damage not only other species but its own, which brings back the debate around massive destruction.

Even if the destruction of the planet, other species, and among humans are highlighted topics in aforesaid novels and stories, these tropes became part of the main plot in Dahl's last children's novel Billy and the Minpins. ${ }^{2}$ The story starts like many other classic fables, Billy's mother warns her child against going to the Forest of Sin where all kinds of dangerous creatures live; the boy disobeys his mom and instead discovers human-like Lilliputian beings that in a Dr. Seuss' Lorax tradition -or even similar to Dahl's gremlins- are the voice of the trees and cooperate with birds, who are they transportation to travel and collect food. The Minpins are threatened by a fearsome beast known as the Gruncher that belches smoke from his nose which makes him blind, but can still smell its prey. Blake's illustrations do not show the Gruncher, leaving it to the imagination of the reader, who can even see it as a metaphor for pollution and the burning of forests.

If we read this narrative from the suggested perspective to study children's environmental books, we could argue that it defeats alienation and hierarchy by placing the child at the same level as the creatures, plants, and animals of the forest because Billy adapts to their way of living to devise the plan to defeat the Gruncher. Following the established cooperation between birds and Minpins, the child is aided by a swan who flies him in and, together, get to trick the beast into falling on a lake which puts out the fire, destroying the Gruncher, so even if Billy becomes the hero, nature preserves its agency. In the end, the Minpins warn the boy that if other humans know about them, they would ruin their forest, introducing again the notion of the inevitable human destruction to the environment.

The lesson that Billy learns is not the typical moral found in fables about not disobeying the elders. On the contrary, as Pinsent argues referring to Dahl's views on education, we see that his writing supports "individual endeavour and outdoor pursuits" $(2012,71)$ and in this story, the protagonist learns that to acquire knowledge on how to respect and protect the environment accurately, he needs to "watch with glittering eyes the whole world around" (Dahl 2019, 81), an idea that is reappraised in Dahl's stories concerning animals which will be addressed next.

\section{SUBTLE ANTHROPOMORPHISM}

Given the predominance of animal fables in children's literature, this theme entered the scope of ecocriticism that seeks to study the rapport between culture and nature, as well as the objectivity and subjectivity regarding animals' representation

\footnotetext{
2 Previously known as The Minpins, the title changed in a 2017 rendition that included illustrations by Quentin Blake.
} 
in these narratives (Gaard 2008, 14). When portraying interspecies' relationships, Dahl's fiction equates children and animals since they are both dominated by adult humans, and even if the latter are usually depicted anthropomorphically, their habitats are drawn from factual learning, while in fewer of these stories animals are presented more realistically.

In this regard, Geerdts argues that

On one hand, anthropomorphism may support analogical reasoning between humans and animals, helping children extend biological knowledge about humans to unfamiliar. On the other hand, anthropomorphism may promote a humancentered view of the biological world and encourage the attribution of humanspecific properties to real animals. $(2016,10)$

Hence, the scholar wonders if we should continue to use this tradition to engage children to learn about the environment and on an argument in favour, Geerdts explains that depictions of animals in storybooks expose children to information about non-human beings that are unfamiliar to them when there is little opportunity to have direct interaction with nature $(2016,11)$. In fact, research supports the idea that anthropomorphism is beneficial to increase psychological connections between humans and nature because personal analogy serves children as a conceptual bridge to help them make educated guesses on biological facts concerning the environment and therefore, storybooks that encourage closeness to the natural world could help foster ecological relations (Geerdts 2016, 12-13). On the other hand, extremely anthropomorphic representations could interfere with factual learning, especially in younger children and therefore, "research that varied the format (e.g., language, illustrations) and degree (e.g., behaviors, physical characteristics) of anthropomorphism suggests that more subtle forms" are effective in teaching students about animals -especially older children and adolescents as they are capable of recognizing metaphor-and hence, these works do not encourage anthropocentric reasoning (Geerdts 2016, 12).

A few works by Dahl provide more anthropomorphic depictions as his picture book The Enormous Crocodile (1978), as well as the Giraffe, The Pelly and $\mathrm{Me}$ (1985), offering a few facts about animals -for instance, what they eat and some of their abilities, but closer to traditional representations originated in fables. In Esio Trot (1990) something similar happens because the pet tortoises work only as a plot device -in the form of a courtship tool used by an old man in love with his neighbour. However, the remark that Dahl makes in the preface shows his concerns when he explains that the English government passed a law prohibiting to bring tortoises from places like North Africa since they used to be brought in boats in terrible conditions (Dahl 2016c, 5-6).

Already, in the short story "The Boy Who Talked with Animals," included in The Wonderful Story of Henry Sugar and Six More (1977) -a book aimed for tweens and teens- Dahl shows his concerns when telling the story of a sea turtle caught by fishermen on a resort beach in Jamaica where the owner expects to cook it as a meal, and rich tourists offer money to transform its shell into fashionable and decoration 
pieces. Fortunately, a boy who can communicate with the turtle ends up running away with the animal to the sea and although alienation is faced in this story, the child is left alone to fight a problem already caused by the adults and in the end, eco-social hierarchy and domination structures do not alter because the grown-up characters do not reformulate their views.

On the other hand, Dahl's works offer several nods on animals that should not be our companions, and neither be at the service of human entertainment and exploitation. The Twits expands this perspective as Mr. and Mrs. Twit are not only mean to each other, but also mistreat their African Muggle-Wump monkeys training them like circus animals. The Roly-Poly Bird -another character, like the Muggle-Wumps, that also reappears in other stories and poems by Dahl- serves as the intermediary between the monkeys and the local birds, as this migrant bird can communicate with both, warning and saving the locals from the Twits' weekly bird pie. Later, they all help the Muggle-Wumps to put everything upside down in the Twits' house, while the couple is out shotgun shopping. Blake's illustrations portray the animals in a cartoonish graceful way that contrasts with the Twits' horrifying appearance (Scott 2012, 169). In this sense, Scott points out how

In the aesthetically remarkable drawings such as those in The Twits, and the serenity of those in My Year, ${ }^{3}$ Blake has captured Dahl's strong sense of the order and moral direction that lie deep in nature and defy the grotesque actions of wicked people, and has affirmed the energy and power of the human spirit working in harmony to set the world to rights. $(2012,173)$

The Twits contain subtler anthropomorphic representations since the behaviour described in the text has been somehow acquired by the training the monkeys have received from the retired ringmasters - even in real life, circus and lab animals, as well as pets and other domesticated animals are at the mercy of humans and behave as taught. Happily, the monkeys end up leaving back to Africa with the Roly-Poly Bird, revisiting the argument that animals and plants should be free and be able to remain in their habitat.

"The Pig," a poem from the Dirty Beasts collection, represents another revenge plot from animal to human and refers to real-life meat consumption -as the BFG argued. In this horror children's bedtime narrative, a highly intelligent pig thinks about his life purpose until he realizes:

They want my bacon slice by slice

To sell at a tremendous price!

They want my tender juicy chops

To put in all the butchers' shops!

${ }^{3}$ In the posthumously published book My Year, based on Dahl's diaries, the author refers to his childhood memories, and describes vegetation and animals' behaviour and how their natural habitat changes through seasons-which are subtly depicted by Blake's watercolour illustrations. 
They want my pork to make a roast

And that's the part'll cost the most!

They want my sausages in strings!

They even want my chitterlings!

The butcher's shop! The carving knife!

That is the reason for my life! (Dahl 2002, 4)

The poem ends on a frightful note when the pig decides to eat his farmer, which exposes how our daily practices may be atrocious to animals. Likewise, in James and the Giant Peach, there is a moment when Miss Spider tells how her relatives died in the most awful ways because of James' aunts. In this sense, Stallcup points out how Dahl "intertwines the oddly related pleasures of humour and disgust in order to create slyly satirical commentary" $(2012,31)$, exposing through these stories how these animal characters dread killing and torturing like humans do, which encourages empathy in the reader.

In this regard, James and the Giant Peach reinforces the child-animal bond and inspires emotional and psychological connection with nature. Even if the insects are illustrated and physically described anthropomorphically -for instance, they are portrayed as tall as James and wearing clothing pieces or accessories like the Centipede's boots- the narrative accentuates biological facts, ${ }^{4}$ for example, how earthworms and ladybirds are useful in farms, how centipedes do not have exactly one hundred legs and how grasshoppers' ears are in their bellies and not in their heads as James assumes, and also how important proves the silk from silkworms and spiders as flies and mosquitoes' catchers, and how beautiful the glowworm can be in our eyes.

Similar to Billy in relation to the Minpins' habitat, along the journey in the giant peach, James is the one that devices the plans to face the challenges in the story, but always considers the crew's abilities, so the boy and the insects end up working together. The child is again set at the same level as the animals and has to act as their intermediary when they first arrive in New York and the citizens are afraid of them. However, the ending is more promising than in the "Boy Who Talked with Animals" and Billy and the Minpins -where the boy has to keep the Minpins' forest as a secret to avoid future destruction- because, finally, the insects are not only welcomed by the youngest, but by the society as a whole.

\section{HUNTERS, THE WORST KIND OF BULLIES}

Putting oneself in nature's shoes and showing empathy to animals is taken to a further level in The Magic Finger where the heroine tries hard to convince her neighbours, the Greggs, to stop shooting animals and birds, but they ignore her

\footnotetext{
4 The only exception could be observed in the beginning when it is mentioned that James' parents were eaten by a rhinoceros, which is not possible as these animals are herbivores.
} 
remarks and make fun of her. The fact that in this story the protagonist is a girl who must confront men about an activity that has been socially regarded as masculine and their reaction towards her emphasizes how she begins from a disempowered position -not only for being young but also for being a woman in this male environmentto one of empowerment when she wisely decides to use her ability. When the girl gets cross, she can point her magic finger at the person that causes her anger, but she tries to restrain herself from using her power because it could unleash terrible consequences. However, after realizing that the Greggs will not listen to her, the girl can no longer restrain herself and points her magic finger to the whole family, including the wife.

After a night out trying to shoot a family of ducks, the Greggs wake up in smaller bodies, with wings instead of arms, and when they decide to fly, they see from above that the ducks have grown and now, instead of wings, have human arms; soon the birds occupy the Gregg's home leaving the humans to build a nest to sleep. The descriptions and illustrations do not show a complete metamorphosis of the humans and the ducks -for instance, the Greggs are still able to speak English, while the ducks keep on quaking most of the time. A bodily deformation, similar to the one in "The Swan" -another story from the Henry Sugar collection, where Dahl equates hunters with the worst kind of bullies- makes the narrative more striking as it plays once more with humour and disgust to foster social commentary (Stallcup 2012, 36-37).

In the morning, after a hard night sleeping in the nest, another terrible surprise awaits the Greggs, they find the ducks pointing their guns in their direction and when they beg the animals not to shoot, the birds adopt for the first time the human language and reply:

\footnotetext{
'Why not?' [...] 'You're always shooting at us.'

'Oh, but that's not the same' said Mr. Gregg. 'We're allowed to shoot ducks!'

'Who allows you?' asked the duck.

'We allow each other,' said Mr. Gregg. (Dahl 2008, 40)
}

Again Dahl points his magic finger to the fact that humans always make one-sided rules regarding the natural world. Even when Mrs. Gregg tries to convince to the ducks not to harm their children, the duck replies: "Yesterday you shot my children' [...] 'You shot all of my six children"' (Dahl 2008, 41). Finally, the ducks make the Greggs promise to destroy their guns and not to shoot another animal again before releasing them, and suddenly, humans and ducks regain their physical appearance. The Greggs not only keep their promise but, to honour the birds, their family name is changed to the Eggs; they also make graves for the ducks they have shot and from then on, feed the birds that arrive at their farm.

In the end, the heroine finds out that another family is out hunting and gets ready to confront them, and as Pennell argues: "the girl child refuses to remain a captive of the private sphere and asserts her right to a voice in the public sphere; she successfully schemes so that male characters foreswear a patriarchal practice" $(2012,108)$. Not only is the child heroine an empowered young girl, but also the 
animals have been capable of standing for themselves and hence, the narrative also defeats another patriarchal construction which is the idea of human hierarchy over the environment because no longer the Greggs feel entitled to hunt or see animals as inferior creatures.

Other works that show this kind of agency are Danny the Champion of the World and Fantastic Mr. Fox, where social inequality is paired with eco-justice problems. In the first novel, Danny and his father live in a caravan, own a gas station, and enjoy poaching pheasants from Mr. Hazel's land -only for their own consumption. On the other hand, the magnate hosts a shooting party each year for the rich and the royals and is already depicted as a bully when he is mean to the boy in the gas station. This leads the father and child to devise a plan to poach all Hazel's pheasants right before the party, thus succeeding. When the magnate frenetically arrives in the gas station to confront the heroes, the birds "exact a gooey, disgust-laden revenge" and occupy Mr. Hazel's Roll Royce scratching and damaging the painting of the car and making a mess (Stallcup 2012, 41), and finally, even to Danny and his father's surprise, the pheasants fly away in the opposed direction to Hazel's land, freeing themselves from all the humans in the story.

In this novel, nature is not depicted anthropomorphically, and once again Dahl's preferential views towards a practical education are emphasized when Danny's father teaches his child facts about birds, insects, frogs, and other animals that they find in their way to school, providing him not only with knowledge about habitats and the countryside but giving also a lesson of ecological respect and "love of the beauty of the natural world that, via Danny's father, Dahl is seeking to generate in the young reader" (Pinsent 2012, 75).

In Fantastic Mr. Fox, the animals also stand up for themselves against the cruel farmers Boggis, Bunce, and Bean, who have the monopoly of food and want to kill any animal that threatens their privilege. Like Danny's father, Mr. Fox steals from the farmers because that is the only way to feed his family even if he risks getting hurt -for instance, the last time he comes to the surface, the farmers try to kill him, but they just shoot off his tail. Later the farmers dig the Foxes' burrow using spades and excavators, but these animals, as natural diggers, manage to go even further underground to remain safe. However, they starve as they cannot go out because the farmers decide not to move from the spot, ready with their shotguns. Mr. Fox finds out how to carve a tunnel to the places where each farmer keeps his livestock, and extends an invitation to the Badger, the Moles, the Rabbits, and the Weasels for a great meal, bringing food for carnivorous and herbivores and tricking the farmers who are still waiting for the fox to come out. According to Scott, Blake's illustrations portray humans as uncivilized and beastly, whilst animals behave wittily (2012, 163), and even if represented anthropomorphically, their behaviour and eating habits are depicted accurately; more importantly, the narrative helps to question human superiority over nature and its creatures. 


\section{POINT OF DEPARTURE}

Dahl's works explore nature deeply and have long been part of the school curricula and accessible in public libraries, aside from the fact that several of these stories have been adapted to films, TV shows, plays and a recent comic book. Considering that Children's and Young Adult fiction holds an aesthetic-didactic aim, ecological literature helps to expand knowledge and encourage the reader to appreciate and preserve the environment since it contributes to the assimilation of ethical values and ideology (Baratz and Hazeira 2011, 34-35). According to Gaard, "when assessing ecojustice problems, students seem to rely more on their emotions than on their intellectual knowledge of environmental science" $(2008,20)$, which grants children's literature a special role to foster ecological and socioeconomic discussions.

In fact, social inequality and power relations are often related to environmental sustainability, which is sometimes overlooked in the narratives we found in children's popular culture (Sturgeon 2004, 262-263). Nevertheless, we have analysed how Dahl builds these important connections through his works for young readers, whether these narratives are partly or entirely devoted to the natural world.

In this regard, Sturgeon argues that

... it is crucially important to examine what stories are being told, what values are being promoted, which actors get to have agency, and what solutions are being offered. What lessons are being learned, and what kind of environmentalism has become the medium of these messages? What connections are made for children between environmentalism and social justice, between nature and morality? (2004, 265).

Dahl's stories encourage a reflection on how much we actually know about the natural world that surrounds us, making us question if education goes in that direction. Through human depictions, especially those of adult males as uncivilized while nature retains its wisdom, as well as through the representation of bodily deformations and alterations among species, these dark fantasies raise awareness on human daily practices that are devastating for the environment and question human superiority over our fellow other-than-human creatures. Particularly, these narratives foster a discussion on how young people can be empowered to engage in eco-activism and suggest a few alternatives. Firstly, an education that encourages harmony with nature; secondly, learning to be assertive as spokespersons on behalf of the environment, with responsibility and respecting nature's agency and, lastly, working to defeat unfair social structures. Consequently, rereading and studying these familiar and beloved stories from an ecological perspective could serve as a good point of departure for inspiring environmental consciousness and agency in children.

Reviews sent to the author: 08/01/2022 Revised paper accepted for publication: 07/02/2022 


\section{WORKS CITED}

Baratz, Lea, and Hanna Abu Hazeira. 2011. “Children's Literature as an Important Tool for Education of Sustainability and the Environment." International Electronic Journal of Environmental Education 2 no. 1: 31-36. ERIC.

DAHL, Roald. (1961) 2016a. James and the Giant Peach. London, New York: Penguin Random House.

Dahl, Roald. (1970) 1998. Fantastic Mr. Fox. London, New York: Penguin Random House.

Dahl, Roald. (1975) 2013. Danny the Champion of the World. New York: Penguin Random House.

DAHL, Roald. (1980) 2014. The Twits. London, New York: Penguin Random House.

DaHL, Roald. (1982) 2016b. The BFG. London, New York: Penguin Random House.

DAHL, Roald. (1983) 2002. “The Pig”. In Dirty Beasts, 3-5. London, New York: Penguin Random House.

DaHL, Roald. (1990) 2016c. Esio Trot. London, New York: Penguin Random House.

DAHL, Roald. (1991) 2019. Billy and the Minpins. New York: Penguin Random House.

DaHL, Roald. (1993) 1994. My Year. New York: Viking.

DaHL, Roald. 1943. The Gremlins. New York: Random House.

Dahl, Roald. 1977. "The Boy Who Talked with Animals". In The Wonderful Story of Henry Sugar and Six More, 1-23. New York: Alfred A. Knopf.

DAHL, Roald.1977. “The Swan”. In The Wonderful Story of Henry Sugar and Six More, 73-98. New York: Alfred A. Knopf.

DAHL, Roald. (1949) 2006. “The Sound Machine”. In Collected Stories, edited by Jeremy Treglown, 201-214. New York: Alfred A. Knopf.

Dahl. Roald. (1966) 2008. The Magic Finger. London, New York: Penguin Random House.

GAARD, Greta. 2008. “Toward an Ecopedagogy of Children's Environmental Literature.” Green Theory \& Praxis: The Journal of Ecopedagogy 4 no. 2: 11-24. https://doi.org/10.3903/gtp.2008.2.3.

GeErdts, Megan S. 2016. “(Un)Real Animals: Anthropomorphism and Early Learning About Animals." Child Development Perspectives 10 no. 1: 10-14. https://doi.org/10.1111/cdep.12153.

Hollindale, Peter. 2011. "Nature.” In Keywords for Children's Literature, edited by Philip Nel and Lissa Paul, 161-164. New York: NYU Press.

Pennell, Beverley. 2012. "When one is with her it is impossible to be bored': An Examination of Roald Dahl's Contribution to a Feminist Project in Children's Literature." In Roald Dahl, edited by Ann Alston and Catherine Butler, 102-122. New York: Palgrave Macmillan.

Pinsent, Pat. 2012. “The problem of school': Roald Dahl and Education.” In Roald Dahl, edited by Ann Alston and Catherine Butler, 70-85. New York: Palgrave Macmillan.

Roald Dahl Story Company Ltd. n.d. "Some Time Never". The Official Roald Dahl Website. Accessed July 30, 2020. https://www.roalddahl.com/roald-dahl/stories/p-t/some-time-never.

Sсотт, Carole. 2012. "Roald Dahl and Quentin Blake." In Roald Dahl, edited by Ann Alston and Catherine Butler, 160-175. New York: Palgrave Macmillan.

Sigler, Carolyn. 1994. "Wonderland to Wasteland: Toward Historicizing Environmental Activism in Children's Literature." Children's Literature Association Quarterly 19 no. 4: 148-153. https://doi.org/10.1353/chq.0.1011. 
Stallcup, Jackie E. 2012. "Discomfort and Delight: The Role of Humour in Roald Dahl's Works for Children.” In Roald Dahl, edited by Ann Alston and Catherine Butler, 31-50. New York: Palgrave Macmillan.

Sturgeon, Noël. 2004. “'The Power Is Yours, Planeteers!' Race, Gender, and Sexuality in Children's Environmentalist Popular Culture." In New Perspectives on Environmental Justice, edited by Stein Rachel, 262-276. New Jersey: Rutgers University Press. 
